https://doi.org/10.46813/2022-137-090

\title{
THE EXPRESS REGISTRATION OF THERMAL CONDUCTIVITY ANOMALIES OF SOLIDS
}

\author{
V.I. Sokolenko, V.A. Frolov, E.S. Savchuk \\ National Science Center "Kharkov Institute of Physics and Technology”, Kharkiv, Ukraine \\ E-mail: vsokol@kipt.kharkov.ua
}

Investigation of the thermophysical characteristics of materials at low temperatures $(\mathrm{T} \leq \Theta, \Theta$ is the Debye temperature) makes it possible to obtain information on the interaction of quasiparticles and is in demand in the applied plan. For the indicated temperatures, a method of express registration (ER) of anomalies in the thermal conductivity of solids $(\mathrm{k})$, which is a variation of the classical method of uniaxial stationary heat flux (USHF), but which, unlike the prototype, does not require taking into account heat losses (HL). A feature of the ER method is the measurement of the temperature dependence of the difference $\delta \mathrm{T}=\mathrm{T}_{1}-\mathrm{T}_{2}$ between the ends of the sample under conditions of simultaneous monotonicity of the change in $\mathrm{T}$ of the sample and all HL. In this case, the measured scaled thermal conductivity $\mathrm{K} \propto(\mathrm{Q} / \Psi) / \delta \mathrm{T}(\Psi$ is a monotonic scale factor in $\mathrm{T}$ ) correlates with the real $\mathrm{k} \propto \mathrm{Q} / \delta \mathrm{T}$. For the interval $300 \ldots 77 \mathrm{~K}$, one of the variants of the ER method was tested, in which a step-by-step movement of the sample in a column of gaseous nitrogen above the surface of liquid $\mathrm{N}_{2}$ in a Dewar vessel was used. In the case of a monotonic change in the distance from the sample to the liquid, the formed configuration of isotherms ensures the monotonicity of the change in $\mathrm{T}$ of the sample and, at the same time, the monotonicity of the HL along the channels of thermal conductivity and radiation. The possibilities of the ER method are illustrated by examples of determining the temperatures and signs of anomalies in the thermal conductivity coefficients of high-temperature superconductors (HTSC) in the pseudogap state (PGS) and a high-entropy alloy $\mathrm{Al}_{0.5} \mathrm{CoCuCrNiFe}$, which is promising for use in the cryogenic temperature range. The method made it possible for the first time to discover the staging of the temperature evolution of the thermal conductivity of $\mathrm{YBa}_{2} \mathrm{Cu}_{3} \mathrm{O}_{7-\mathrm{x}}$ and $\mathrm{Bi}_{1.6}\left(\mathrm{~Pb}_{0.4}\right) \mathrm{Sr}_{2} \mathrm{Ca}_{2} \mathrm{Cu}_{3} \mathrm{O}_{10+\mathrm{x}}$ in the PGS and to determine the temperatures and signs of the anomalies. The data obtained convincingly confirmed the results of probing the PGS of HTSCs by the method of polarized neutron scattering carried out with the participation of a number of EU research institutes. Also, for the first time, an extended thermal conductivity anomaly of a high-entropy $\mathrm{Al}_{0.5} \mathrm{CoCuCrNiFe}$ alloy in the range of $\sim 220 \ldots 170 \mathrm{~K}$ was discovered, which is probably a consequence of changes in the configuration of the Fermi surface.

PACS: 44.10.+i; 45.40.-b; 61.82.Bg

\section{INTRODUCTION}

The key idea of the method of express registration (ER) of anomalies in the thermal conductivity of solids is the same as in the uniaxial stationary heat flow method [1] which consists in the following. Along a homogeneous cylindrical rod (section $\mathrm{S}=\pi \mathrm{d}^{2} / 4$, $\mathrm{d}-$ diameter), generated a uniaxial stationary heat flux $\mathrm{Q}$ causing a temperature drop $\delta \mathrm{T}=\mathrm{T}_{1}-\mathrm{T}_{2}$ between the ends of the rod. For $\mathrm{Q}$ to be uniaxial and stationary it is necessary that the surface of the sample be perfectly insulated, and $1 / d \gg 1$, where 1 is distance between sections where $T_{1}$ and $T_{2}$ were measured. In this case the thermal conductivity coefficient $\mathrm{k}$ is described by the Fourier formula $\mathrm{k}=(\mathrm{Q} / \delta \mathrm{T}) \times 1 / \mathrm{S}$ and the error in $\mathrm{k}$ is associated with errors in measurements of $\mathrm{Q}, \delta \mathrm{T}$, and $\mathrm{S}$. The most difficult problem in [1] is the measurement of Q. The reason is the presence of various heat losses (HL) because the actual Q differs from experimentally measured value $\mathrm{Q}^{*}>\mathrm{Q}$. Therefore in practice are used different methods to reduce $\mathrm{HL}$ to the level of $\mathrm{Q} \cong \mathrm{Q}^{*}$.

Of three HL canals - at the expense of thermal conductivity and convection of contact gas (I), along supplying wires (II), at the expense of radiation from sample surface (III) - the canal I is being most easy overlapped by placing the sample in vacuum $\sim 10^{-4} \mathrm{~Pa}$. Dispersion at the expense of canal II also one may decrease without problems to enough small value. The most problematical in [1] are radiation losses (canal III). To their minimizing the sample is being surrounded by anti-radiation screen along which one being created the same drop of temperature by means of additional heaters. That way however may compensate only normal component of radiation. To compensate tangential one an active heat screen is being applied [2]. Strong following enumerated demands allows to reach the precision of $\mathrm{k}$ determination $\sim 0.1 \%$ [3]. While neglecting anti-radiation screen is being increased the mistake to $\sim 25 \%$ [4]. Problems of $\mathrm{Q}$ definition are increasing when it is necessary to investigate an extensive temperature interval and not overcome for short samples having not circular cross-sections along axis.

Meanwhile there are number of problems connected with investigation of crystal lattice's temperature behaviour and energy spectra characteristics of «non classic form» samples in which as a tool may use heat transfer kinetics. In spite of this the goal of such investigations limited often by determination of temperatures and signs of $\mathrm{k}$-anomalies. Of no small importance is sometimes a desirability of expresstesting big number of samples (for example at look over the chemical composition variations of high-entropy alloys). One of methods for the problem decision considered below.

\section{THE ESSENCE OF THE METHOD}

Suppose that it is required to determine the temperatures and signs of the anomalies of the 
dependence $k(T)$ in the interval $T_{0}-T$ for $a$ homogeneous sample whose shape differs from cylindrical one, and let there be the HL through channels I-III. As characteristic of $\mathrm{k}$ we take like [1] the temperature difference $\delta \mathrm{T}=\mathrm{T}_{1}-\mathrm{T}_{2}$ between the ends of the sample arising as a result of applying a heat flux to one of them. As for the source of thermal power of the nominal value $\mathrm{Q}^{*}=$ const, then this is an electric heater (H) - either located at the end of the sample or remote from it and equipped with a heat conductor (HT), Fig. 1, insert.

Imagine that the sample is divided into $\mathrm{n}$ transversal disks of thickness $\delta \mathrm{x} \rightarrow 0$ which have the same $\mathrm{k}$ due to the homogeneity of the material. We may write the obvious expression for the temperature difference $\delta \mathrm{T}$ between the surfaces limiting the body of the 1-st disk:

$$
\delta \mathrm{T}_{1} \propto(1 / \mathrm{k}) \times\left(\mathrm{Q}^{*}-\mathrm{Q}_{1 \text { loss }}\right),
$$

where $\mathrm{Q}_{1 \text { loss }}$ is the $\mathrm{HL}$ on 1-st disk. For the second disk it is similar:

and, finally, for the $\mathrm{i}$-th disk it is

$$
\delta \mathrm{T}_{2} \propto(1 / \mathrm{k}) \times\left(\mathrm{Q}^{*}-\mathrm{Q}_{1 \text { loss }}-\mathrm{Q}_{2 \text { loss }}\right)
$$

Summing up over $\delta \mathrm{T}_{\mathrm{i}}$ :

$$
\delta \mathrm{T}_{\mathrm{i}} \propto(1 / \mathrm{k}) \times\left(\mathrm{Q}^{*}-\mathrm{Q}_{1 \text { loss }}-\mathrm{Q}_{2 \text { loss } \ldots} \ldots-\mathrm{Q}_{\mathrm{iloss}}\right) .
$$

$$
\begin{gathered}
\sum \delta \mathrm{T}_{\mathrm{i}} \equiv \delta \mathrm{T} \propto(1 / \mathrm{k}) \times\left[\left(\mathrm{Q}^{*}-\mathrm{Q}_{1 \text { loss }}\right)+\left(\mathrm{Q}^{*}-\mathrm{Q}_{1 \text { loss }}-\mathrm{Q}_{2 \text { loss }}\right)+\right. \\
\left.+\left(\mathrm{Q}^{*}-\mathrm{Q}_{\text {lloss }}-\mathrm{Q}_{2 \text { loss }}-\mathrm{Q}_{\text {iloss }}\right)\right],
\end{gathered}
$$

we obtain:

$$
\delta \mathrm{T} \propto(1 / \mathrm{k}) \times\left[\mathrm{nQ}^{*}-\mathrm{nQ}_{1 \text { loss }}-(\mathrm{n}-1) \mathrm{Q}_{2 \text { loss }}-(\mathrm{n}-2) \mathrm{Q}_{3 \text { loss }}-\ldots-\right.
$$$$
\left.(n-i+1) Q_{\text {iloss }}\right] \text {. }
$$

We immediately notice that the greater the total HL the smaller the square bracket in (1), in other words, the less $\delta \mathrm{T}$ in comparison with the case of no HL.

Let suppose next conditions carried out for interval $\mathrm{T}_{0}-\mathrm{T}$ : i) the sample temperature varies monotonic; ii) the HL on canals I-III varies monotonic with T. In that case quadratic bracket in (1) may be substitutes by quotient $\mathrm{Q}^{*} / \Psi(\mathrm{T})$, were $\Psi(\mathrm{T})>1$ is dimensionless coefficient being monotonous function of $\mathrm{T}$ :

$$
\delta \mathrm{T} \propto(1 / \mathrm{k}) \times\left(\mathrm{Q}^{*} / \Psi\right)=\mathrm{Q} * / \mathrm{k} \Psi .
$$

Then the ratio of experimentally measuring values $\delta \mathrm{T}$ for $\mathrm{T}_{0}$ and $\mathrm{T}$ will be

$$
\delta \mathrm{T}_{0} / \delta \mathrm{T} \propto(\mathrm{k} \times \Psi) /\left(\mathrm{k}_{0} \times \Psi_{0}\right) .
$$

Designating $(\mathrm{k} \times \Psi) \equiv \mathbb{K}$ and $\left(\mathrm{k}_{0} \times \Psi_{0}\right) \equiv K_{0}$ one receive

$$
\delta \mathrm{T}_{0} / \delta \mathrm{T} \propto \mathrm{K} / \mathrm{K}_{0} \text {. }
$$

One can see coefficient $\Psi(\mathrm{T})>1$ has the meaning of monotonic on $\mathrm{T}$ "coefficient of scaling" characterizing the deviation of experimentally defined "scaled coefficient of thermal conductivity $K$ " from real value of k. From (4) follows in one's turn that possible anomalies of the dependence $\delta \mathrm{T}_{0} / \delta \mathrm{T}(\mathrm{T})$ for range $\mathrm{T}_{0}-\mathrm{T}$ must be attributed - but only in case of monotony of function $\Psi(\mathrm{T})$ - to the expense of the dependence $K(\mathrm{~T})$ anomalies, and well then of the dependence $k(T)$ anomalies.

\section{THE EXPERIMENT'S CONDUCTING FOR EXPRESS REGISTRATION OF THE DEPENDENCE $k(T)$ ANOMALIES IN RANGE 300...77 K}

One of variants of ER was applied [5-7] to decision of number of actual physical problems. In the capacity of thermal field (TF) which gave sample temperature $T_{s}$ was utilized the gradient thermal field of gaseous nitrogen over liquid one being in vertically oriented metallic Dewar vessel $\sim 500 \mathrm{~mm}$, inner diameter $\sim 60 \mathrm{~mm}$. To experiment was being selected an cylindrical segment of $\mathrm{TF} \sim 300 \mathrm{~mm}$ long which temperature is constant on azimuth in horizontal sections and decrease monotonously by decreasing distance to liquid refrigerant. The last circumstance predetermined the regime and the way of $\mathrm{T}_{\mathrm{s}}$ variation approaching horizontally oriented sample to liquid refrigerant surface. In this case monotony of decreasing $\mathrm{T}_{\mathrm{s}}$ has guarantied by monotony of distance changing from sample to liquid level and in one's turn monotony of HL losses on canals I, III. To $\delta$ T creation the thermal flux was puts to one of sample end from constantan coil $\mathrm{H}$ with direct current I (see insert on Fig. 1). The monotony of the HL from $\mathrm{H}, \mathrm{HT}$ and leading wires (canal II) has provided by strict constancy of I during experiment.

In common case the number of testing thermalized states in range $\left(\mathrm{T}_{0}-\mathrm{T}\right) \sim 200 \mathrm{~K}$ may consists $\sim 40 \ldots 50$. Then the temperature interval between next points will be $4 \ldots .5 \mathrm{~K}$ and the sensitivity of fixing of anomalies temperatures is defined by sensitivity of measuring temperature difference between next sample positions. It is $\sim 1 \mathrm{~K}$.

In conclusion of the section pay attention once again to the fact that by approaching the sample to liquid refrigerant the values of measuring $\delta \mathrm{T}(\mathrm{T}) \propto 1 / \mathrm{k}(\mathrm{T})$ are smaller in comparison with idealized case of HL absent. So to that a graph of dependence $\mathrm{k}(\mathrm{T})$ turns out in monotonously stretched scale.

Several examples of the definition of temperatures and signs of thermal conductivity anomalies of number of actual physic objects by means of described way listed below.

\section{THERMAL CONDUCTIVITY ANOMALIES OF THE HIGH-TEMPERATURE SUPERCONDUCTORS BEING IN THE PSEUDOGAP STATE}

The question about of the nature of the pseudogap state (PGS) [8] of holy high-temperature superconductors (HTSC) is the most intriguing in the theory of HTSC. It is considered that its decision may give a key for understanding how to raise $T_{C}$. But not clear till now what of the numerous PGS' models (see reviews $[9,10])$ corresponds to reality.

It should be marked that practically all physical characteristics of holy HTSCs demonstrate in the PGS non-Fermi liquid behaviour. As regards the thermal conductivity all investigations were carried out [11-17, et al.] before the discovering the pseudogap $\left(\Delta^{*}\right)$ phenomenon. Perhaps, therefore, an anomalous decrease of $\mathrm{k}$ at $\mathrm{T}<\mathrm{T}^{*}$ [11-17, et al.] was not given proper significance, despite its correlation with the anomaly of the electrical conductivity. The last consists in the appearance of the excess conductivity, which is in obvious contradiction with the Wiedemann-Franz law.

There were and other circumstances induced us to return to investigations of dependence $k(T)$ for holy HTSCs. One of such circumstances was the discovery of the unknown magnetic superstructure in the PGS [18-23] closely associated with appearance of anti- 
ferromagnetic order in the orbital currents of the basic flatness $a b\left(\mathrm{CuO}_{2}\right)$. Besides significance of the same discovery there were the number of experimental data [24-27] allowed assume availability for discovered superstructure of such curious peculiarity as staged its evolution with temperature being obviously by the consequence of Fermi surface staged of temperature evolution. The later question in one's turn is one of significant problem of the HTSC theory.

In connection with account we measured the temperature dependences $\delta \mathrm{T}_{0} / \delta \mathrm{T}(\mathrm{T}) \propto \mathrm{K}(\mathrm{T}) / \mathrm{K}_{0} \propto \mathrm{k}(\mathrm{T}) / \mathrm{k}_{0}$ in range $\sim 300 \ldots 77 \mathrm{~K}$ for HTSCs $\mathrm{Bi}_{1.6}\left(\mathrm{~Pb}_{0.4}\right) \mathrm{Sr}_{2} \mathrm{Ca}_{2} \mathrm{Cu}_{3} \mathrm{O}_{10+\mathrm{x}}$ and $\mathrm{YBa}_{2} \mathrm{Cu}_{3} \mathrm{O}_{7-\mathrm{x}}[5,6]$ using ER method. On Fig. 1a showed the dependence $\delta \mathrm{T}_{0} / \delta \mathrm{T}(\mathrm{T})$ for $\mathrm{YBa}_{2} \mathrm{Cu}_{3} \mathrm{O}_{7-\mathrm{x}}[6]$, and on Fig. $1 \mathrm{~b}-$ the result of measuring dependence $\mathrm{k}(\mathrm{T})$ by the method [1] for analogous sample of $\mathrm{YBa}_{2} \mathrm{Cu}_{3} \mathrm{O}_{7-\mathrm{x}}$. Comparison of Fig. 1a, with Fig. 1b demonstrates, first of all, adequateness of worked up ER-method. From comparison of the figures follows also that dependence $\delta \mathrm{T}_{0} / \delta \mathrm{T} \propto \mathrm{K}[\mathrm{T}, \Psi(\mathrm{T})] \equiv \mathrm{k}(\mathrm{T}) \times \Psi(\mathrm{T})$ is the image of the dependence $\mathrm{k}(\mathrm{T})$ presented in monotony stretched scale.

The scientific meaning obtained results regarding the PGS' nature consist in follows. Firstly discovered four anomalies of thermal conductivity of cuprate $\mathrm{YBa}_{2} \mathrm{Cu}_{3} \mathrm{O}_{7-\mathrm{x}}$ having sign "_"“ - No. 1-4 on Fig. 1a (anomaly No. 5 associated with the structure feature [6]). Mentioned four anomalies indicate: i) on staged character of temperature evolution of the $\Delta^{*}$, that agreeing with [24-27], and ii) on appearance of additional canal of heat carriers scattering in the PGS. Analogous data was obtained concern of thermal conductivity of $\mathrm{Bi}_{1.6}\left(\mathrm{~Pb}_{0.4}\right) \mathrm{Sr}_{2} \mathrm{Ca}_{2} \mathrm{Cu}_{3} \mathrm{O}_{10+\mathrm{x}}$ in PGS [5].

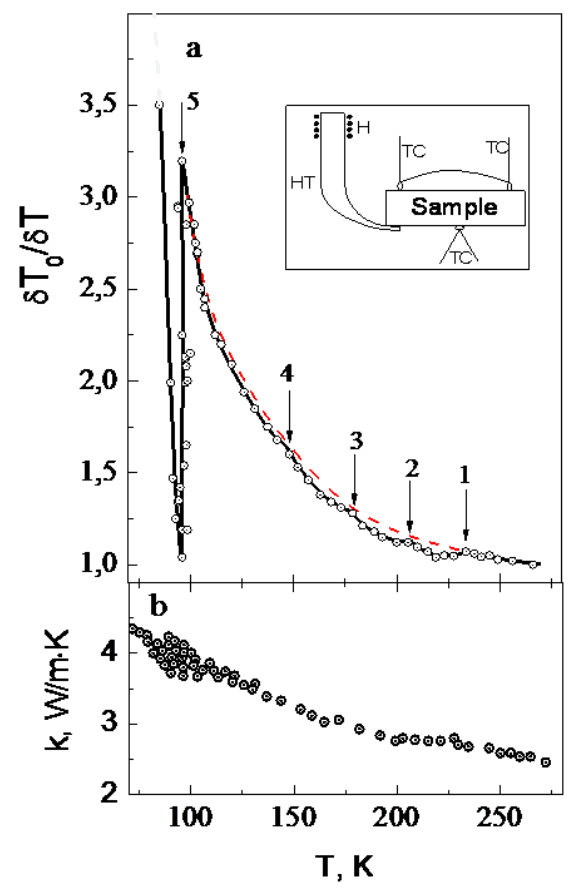

Fig. 1. Solid curve - the graph of dependence $\delta T_{0} / \delta T \propto K / K_{0}$ for $Y B a_{2} C_{3} \mathrm{O}_{7-x}$, measured by ER method; dashed line (red online) - the same dependence graph in assumption of absence of thermal anomalies of $k,[6]$ (a); part of the dependence $k(T)$ from [16] (b). Insert: $H$-electrical heater; $H T$ - heat transfer; TC-thermocouples
In connection with conclusion ii) one would like take the notice that sign of k-anomalies in PGS must be used as effective criterion of adequateness of the PGS' theoretical models. Let's examine on that score the "phase fluctuation" model [28,29]. Opening PG is result of appearance in electronic subsystem of uncorrelated fluctuating Cooper pairs (FCP). Let ask the question: is FCP's availability compatible with appearance of additional canal of phonons dispersion (main heat carriers in HTSCs) i.e. with k-anomaly having sign "_-"?

The results of numerous experiments [11-17, et al.] have indicated that forming below $\mathrm{T}_{\mathrm{C}}$ of ensemble of correlated Cooper pairs initiates strong increasing thermal conductivity, i.e. k-anomaly with sign “+”. This has explained by "cutting off" these quasi-particles from heat carriers scattering. Therefore uncorrelated CPs near $\mathrm{T}^{*}$ should realize analogous sign of the effect in $\mathrm{k}$, i.e. " + ". Hence the «phase fluctuation» model $[28,29]$ do not attribute to number of acceptable PGS' models.

\section{LOW-TEMPERATURE THERMAL CONDUCTIVITY ANOMALY OF THE HIGH-ENTROPY ALLOY $\mathrm{Al}_{0.5} \mathrm{CoCuCrNiFe}$}

The search for anomalies in the thermal conductivity of high-entropy alloy (HEA) $\mathrm{Al}_{0.5} \mathrm{CoCuCrNiFe}$ in range $\sim 300 \ldots 77 \mathrm{~K}$ was a part of comprehensive study of its kinetic characteristics at cryogenic temperatures [7]. Prior to this, there were indirect evidences of possibility of phase transition below $\sim 200 \mathrm{~K}[30,31]$. At the same time, the behaviour of dynamic Young's modulus [31] cast doubt on this possibility. It might be as well to obtain reliable data on the kinetic properties of $\mathrm{Al}_{0.5} \mathrm{CoCuCrNiFe}$ in cryogenic range by various methods. Below, as an illustration of the capabilities of the ER technique, the data on temperature behaviour of the scaled thermal conductivity coefficient $\mathrm{K}$ of the $\mathrm{Al}_{0.5} \mathrm{CoCuCrNiFe}$ are presented.

Fig. 2 illustrates the temperature dependences $\delta \mathrm{T}_{0} / \delta \mathrm{T} \propto \mathrm{K} / \mathrm{K}_{0} \propto \mathrm{k} / \mathrm{k}_{0}$ for annealed samples of $\mathrm{Al}_{0.5} \mathrm{CoCuCrNiFe}$. To verify the heat transfer results we used an absolutely reliable technique for measuring the temperature dependence of the thermoelectric power, $\mathrm{S}(\mathrm{T})$.

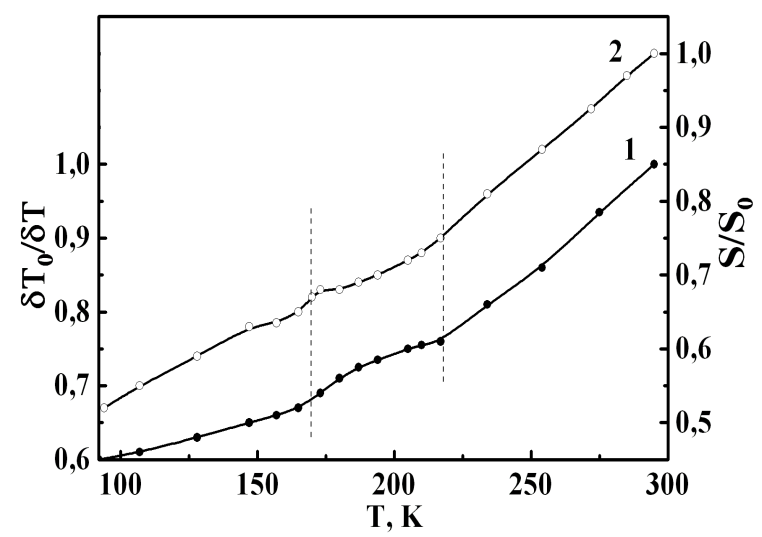

Fig. 2. Dependences: $1-\delta T_{0} / \delta T \propto K / K_{0}$; 2 - $\mathrm{S} / \mathrm{S}_{0}$ for $\mathrm{Al}_{0.5} \mathrm{CoCuCrNiFe}$

It can be seen each curve have pronounced correlating anomaly in the region of $\sim 210 \ldots 170 \mathrm{~K}$ that, 
firstly, indicates the adequacy of the obtained data on the temperature behaviour of $\mathrm{k}$. As for the actual form of the temperature dependence of $\mathrm{k}$, it is typical for a classical metal $(\mathrm{k} \propto \mathrm{T})$, from which it follows that heat transfer is largely provided by phonons.

It seems interesting and requires further study the fact that anomaly slow down the decrease of thermal conductivity with decreasing $\mathrm{T}$. To interpret this fact, it is important that the thermoelectric power, in turn, experiences an anomaly of the same sign. The latter points to the origin of the anomaly - this is clearly not a structural feature, but a feature associated with the electronic subsystem. An additional argument in favor of this version is the significant length of the temperature anomaly. This detail seems to indicate a change in the configuration of the Fermi surface.

\section{CONCLUSIONS}

1. For express registration of the temperatures and the signs of anomalies in thermal conductivity coefficient $\mathrm{k}$ of solids, a variant of the uniaxial stationary heat flux method proposed that does not require of $\mathrm{HL}$ accounting. A prerequisite for the feasibility of the ER is the monotony of changes in the HL during the monotonic change of sample temperature. In this case, the temperature difference $\delta \mathrm{T}$ between ends of sample turns out to be a scaled indicator of $\mathrm{k}: \quad \delta \mathrm{T} \propto(1 / \mathrm{k}) \propto(1 / \mathrm{K})$, where $\mathrm{K} \equiv \mathrm{k} \times \Psi$, $(\Psi(\mathrm{T})>0)$ is the scaled thermal conductivity.

2. For the interval $\sim 300 \ldots 77 \mathrm{~K}$ the experimental configuration of method ER was tested in which sample temperature is determined by its position in the thermal field of gaseous nitrogen in a Dewar vessel with liquid $\mathrm{N}_{2}$. Adequacy of the method is twice demonstrated: i) by comparing the data of the dependence $\mathrm{k}(\mathrm{T})$ of the HTSC $\mathrm{YBa}_{2} \mathrm{Cu}_{3} \mathrm{O}_{7-\mathrm{x}}$ with the dependence $\mathrm{k}(\mathrm{T})$ of a similar $\mathrm{YBa}_{2} \mathrm{Cu}_{3} \mathrm{O}_{7-\mathrm{x}}$ measured by uniaxial stationary heat flux method; ii) by comparison the data of the dependence $\mathrm{k}(\mathrm{T})$ for high-entropy alloy $\mathrm{Al}_{0.5} \mathrm{CoCuCrNiFe}$ with the temperature dependence of the thermoelectric power of the same samples, measured by the approved method.

3. The dependencies $k(T)$ for HTSCs being in the PGS indicate that appearance of the pseudogap on the Fermi level is accompanied by increasing the heat carriers dispersion. It is suggested to use this feature as effective criterion of the adequateness of the PGS' theoretical models.

4. It was found for the first time the lengthy on $\mathrm{T}$ the thermal conductivity anomaly of the high-entropy alloy $\mathrm{Al}_{0.5} \mathrm{CoCuCrNiFe}$ in interval $\mathrm{T} \sim 210 \ldots 170 \mathrm{~K} /$ It correlates with the anomalies of the thermoelectric power coefficient. The length of the anomaly pointed out very likely on changes in the configuration of the Fermi surface.

\section{REFERENCES}

1. M.M. Popov. Termometriya i kalorimetriya. M.: Izd. Mosk. universiteta, 1954, 642 p. (in Russian).

2. I.N. Krupskiy, D.G. Dolgopolov, V.G. Mangeliy, L.A. Koloskova // Ingenerno-fizicheskiy jurnal. 1965, v. 8, N 1, p. 11 (in Russian).
3. C. Uher, A.B. Kaiser, E. Gmelin // Phys. Rev. 1987, B36, N 10, p. 5680.

4. B.A. Merisov. Dissert. na soiskanie uchenoy stepeni d.f.-m.n. KGU im. A.M. Gorkogo, 1989, 259 p. (in Russian).

5 V.A. Frolov, V.I. Sokolenko // JETP Lett. 2018, v. 107, N 7, p. 418.

6. V.I. Sokolenko, V.A. Frolov // JETP Lett. 2019, v. 109, N 8, p. 525.

7. V.N. Voyevodin, V.A. Frolov, E.V. Karaseva, I.V. Kolodiy, E.V. Savchuk, V.I. Sokolenko, T.M. Tikhonovskaya, A.S. Tortika // VANT. Series "Vakuum, chistye materialy, sverchprovodniki". 2020, N 1(125), p. 78 (in Russian).

8. T. Timusk, B. Statt // Rep. Prog. Phys. 1999, v. 62 , p. 61 .

9. V.M. Loktev, R.M. Quik, S.G. Sharapov // Phys. Rep. 2001, v. 349, p. 1.

10. A.A. Kordyuk // Low Temp. Phys. 2015, v. 41, N 5, p. 319-346.

11. A. Jezowski, A. Mucha, J. Zalewski, et al. // Phys. Lett. A. 1988, v. 27, N 4, p. 225.

12. V. Bayot, F. Delannay, C. Dewitte, et al. // Sol. St. Comm. 1987, v. 63, N 11, p. 983.

13. J.D.T. Morelly, J. Heremans, D.E. Swets // Phys. Rev. 1987, v. B36, N 7, p. 3917.

14. B. Salce, R. Calemzuk, C. Ayache, et al. // Physica C. 1988, v. 153-155, p. 1014.

15. B.A. Merisov, G.Ya. Khadzhai, A.P. Voronov, D.A. Gavrenko, A.V. Sologubenko // FNT. 1990, v. 16, N 5, p. 647 (in Russian).

16. A.V. Bondarenko, O.A. Gavrenko, B.A. Merisov, M.A. Obolenskiy, A.V. Sologubenko, G.Ya. Chadjay // FNT. 1991, v. 17, N 3, p. 318 (in Russian).

17. E. Gmelin // FNT. 1990, v. 16, N 5, p. 555.

18. A. Kaminski, S. Rosenkranz, H.M. Fretwell, J.C. Campuzano, Z. Li, H. Raffy, W.G. Gullen, H. You, C.G. Olson, C.M. Varma, H. Höchst // Nature. 2002, v. 416 , p. 610.

19. B. Faugué, Y. Sidis, V. Hinkov, S. Pailhés, C.T. Lin, X. Chaud, and P. Bourges // Phys. Rev. Lett. 2006, v. 96, p. 197001.

20. Y. Sidis, C Ulrich, P. Bourges, C. Bernard, C. Niedermayer, L.P. Regnault, N.H. Andersen, B. Keimer // Phys. Rev. Lett. 2001, v. 86, N 18, p. 4100. 21. Y. Li, V. Balédent, N. Barišić, Y. Cho, B. Faugué, Y. Sidis, G. Yu, X. Zhao, P. Bourges, M. Greven // Nature. 2008, v. 455, p. 372.

22. L. Mangin-Thro, Y. Sidis, P. Bourges, S. De Almeida-Didry // Phys. Rev. 2014, v. B89, p. 094523.

23. C.M. Varma // Phys. Rev. 2006, v. B73, p. 155113.

24. K.K. Gomes, A.N. Pasupathy, A. Pushp, S. Ono, Y. Ando, A. Yazdani // Nature. 2007, v. 447, p. 569.

25. M. Ferrero, P.S. Cornaglia, L. De Leo, O. Parcollet, G. Kotliar, A. Georges // Phys. Rev. 2009, v. B80, p. 064501.

26. T. Kondo, A.D. Palczewski, Y. Hamaya, T. Takeuchi, J.S. Wen, G. Gu, A. Kaminski // Phys. Rev. Lett. 2013, v. 111, p. 157003.

27. Y. He, Y. Lin, M. Zech, A. Soumyanarayanan, M.M. Yee, T. Williams, M.C, Boyer, K. Chatterjee, W.D. Wise, I. Zeljkovic, T. Kondo, T. Takeuchi, 
H. Ikutava, P. Mistark, R.S. Markiewicz, A. Bansil, S. Sachdev, E.W. Hudson, J.E. Hoffman // Science. 2014, v. 344, p. 608.

28. B.K. Chakraverty, A. Taraphder, M. Avignon // Physica C. 1994, v. 235, p. 2323.

29. V.J. Emery, S.A. Kivelson // Nature. 1994, v. 374, p. 434.
30. M.A. Laktionova, E.D. Tabachnikiva, Z. Tang, P.K. Liu // FNT. 2013, v. 39, N 7, p. 814 (in Russian).

31. E.D. Tabachnikiva, M.A. Laktionova, Yu.A. Semerenko, S.E. Shumilin, A.V. Podolskiy, M.A. Tichonovskiy, I. Mishkyf, K. Chach // FNT. 2017, v. 43, N 9, p. 1381 (in Russian).

Article received 01.10.2021

\section{ЭКСПРЕСС-РЕГИСТРАЦИЯ НИЗКОТЕМПЕРАТУРНЫХ АНОМАЛИЙ ТЕПЛОПРОВОДНОСТИ ТВЕРДЫХ ТЕЛ}

\section{В.И. Соколенко, В.А. Фролов, Е.С. Савчук}

Исследование теплофизических характеристик материалов в области низких температур (Т $\leq \Theta, \Theta-$ температура Дебая) дает возможность получать информацию о взаимодействии квазичастиц и востребовано в прикладном плане. Для указанных температур предложен метод экспресс-регистрации (ЭР) аномалий коэффициента теплопроводности твердых тел $(\mathrm{k})$, являющийся разновидностью классического метода одноосного стационарного теплового потока (ОСТП), но который, в отличие от прототипа, не требует учета тепловых потерь (ТП). Особенностью метода ЭР является измерение температурной зависимости разности $\delta \mathrm{T}=\mathrm{T}_{1}-\mathrm{T}_{2}$ между концами образца в условиях одновременной монотонности изменения Т образца и всех ТП. В этом случае измеряемый масштабированный коэффициент теплопроводности $\mathrm{K} \propto(\mathrm{Q} / \Psi) / \delta \mathrm{T}$ коррелирует с реальным $\mathrm{k} \propto \mathrm{Q} / \delta \mathrm{T}$ ( $\Psi$ - монотонный по Т коэффициент масштаба). Для интервала $300 \ldots 77 \mathrm{~K}$ апробирован один из вариантов метода ЭР, в котором используется пошаговое перемещение образца в столбе газообразного азота над поверхностью жидкого $\mathrm{N}_{2}$ в сосуде Дьюара. В случае монотонного изменения расстояния от образца до жидкости сформировавшаяся конфигурация изотерм обеспечивает монотонность изменения Т образца и одновременно - монотонность ТП по каналам теплопроводности и излучения. Возможности метода ЭР проиллюстрированы примерами определения температур и знаков аномалий коэффициентов теплопроводности высокотемпературных сверхпроводников (ВТСП) в псевдощелевом состоянии (ПЩС) и перспективного для применения в области криогенных температур высокоэнтропийного сплава $\mathrm{Al}_{0,5} \mathrm{CoCuCrNiFe}$. Метод позволил впервые обнаружить стадийность температурной эволюции теплопроводности ВТСП $\mathrm{YBa}_{2} \mathrm{Cu}_{3} \mathrm{O}_{7-\mathrm{x}}$ и $\mathrm{Bi}_{1,6}\left(\mathrm{~Pb}_{0,4}\right) \mathrm{Sr}_{2} \mathrm{Ca}_{2} \mathrm{Cu}_{3} \mathrm{O}_{10+x}$ в ПШС и определить температуры и знаки аномалий. Полученные данные убедительно подтвердили результаты зондирований ПЩС ВТСП методом рассеяния поляризованных нейтронов, проведенных с участием ряда исследовательских институтов ЕС. Также впервые обнаружена протяженная аномалия теплопроводности высокоэнтропийного сплава $\mathrm{Al}_{0,5} \mathrm{CoCuCrNiFe}$ в интервале 220...170 K, являющаяся, вероятно, следствием изменений конфигурации поверхности Ферми.

\section{ЕКСПРЕС-РЕССТРАЩЯ НИЗЬКОТЕМПЕРАТУРНИХ АНОМАЛІЙ ТЕПЛОПРОВІДНОСТІ ТВЕРДИХ ТІЛ}

\section{В.І. Соколенко, В.О. Фролов, С.С. Савчук}

Дослідження теплофізичних характеристик матеріалів в області низьких температур (T $\leq \Theta, \Theta-$ температура Дебая) дає можливість отримувати інформацію про взаємодію квазічастинок і є затребуване у прикладному плані. Для вказаних температур запропоновано метод експрес-реєстрації (ЕР) аномалій коефіцієнта теплопровідності твердих тіл $(\mathrm{k})$, що $\epsilon$ різновидністю класичного методу одновісного стаціонарного теплового потоку (ОСТП), який не потребує, на відміну від прототипу, урахування теплових втрат (ТВ). Особливістю методу ЕР є вимір різниці $\delta \mathrm{T}=\mathrm{T}_{1}-\mathrm{T}_{2}$ між кінцями зразка в умовах одночасної монотонності змін Т зразка і величин всіх ТВ. У цьому випадку вимірюваний масштабований коефіцієнт теплопровідності $K \propto(\mathrm{Q} / \Psi) / \delta \mathrm{T}$ корелює з реальним коефіцієнтом теплопровідності $\mathrm{k} \propto \mathrm{Q} / \delta \mathrm{T}(\Psi-$ монотонний за Т коефіцієнт масштабу). Для інтервалу $300 \ldots 77 \mathrm{~K}$ апробовано один 3 варіантів методу ЕР, в якому використовується покрокове переміщення зразка в стовпі газової фази над поверхнею рідкого азоту в посудині Дьюара. У разі монотонної зміни відстані від зразка до рідкого холодоагенту сформована конфігурація ізотерм забезпечує монотонність змін температури зразка і водночас - монотонність ТВ по каналах теплопровідності і випромінювання. Можливості ЕР проілюстровані прикладами визначення температур і знаків аномалій коефіцієнтів теплопровідності високотемпературних надпровідників (ВТНП) у псевдощілинному стані (ПЩС) і перспективного для використання в царині криогенних температур високоентропійного сплаву $\mathrm{Al}_{0,5} \mathrm{CoCuCrNiFe}$. Метод дозволив вперше виявити стадійність температурної еволюції теплопровідності ВТНП $\mathrm{YBa}_{2} \mathrm{Cu}_{3} \mathrm{O}_{7-\mathrm{x}} \mathrm{i} \mathrm{Bi}_{1,6}\left(\mathrm{~Pb}_{0,4}\right) \mathrm{Sr}_{2} \mathrm{Ca}_{2} \mathrm{Cu}_{3} \mathrm{O}_{10+x}$ у ПЩС, а також встановити температури і знаки аномалій. Отримані дані переконливо підтвердили результати зондувань ПЩС ВТНП методом розсіювання поляризованих нейтронів, проведених за участю ряду дослідницьких інститутів ЄС. Також уперше виявлено протяжну аномалію теплопровідності високоентропійного сплаву $\mathrm{Al}_{0,5} \mathrm{CoCuCrNiFe}$ в інтервалі $\sim 220 \ldots 170 \mathrm{~K}$, що, вірогідно, є наслідком змін конфігурації поверхні Фермі. 